\title{
Production of Thiophene from Tagetus patula
}

Anisha Brigit Shajan*, Anooja PA, Mitha VM, Neethu Paulson, Sanooja K, Sushitha T Nair, and Praveena P

Department of Biotechnology, Sahrdaya College of Engineering and Technology, Kerala, India

\begin{abstract}
Thiophene chemistry proved to be very interesting for several industrial branches. The thiophene moiety was found to have larvicidal action on mosquito larvae. Thiophene is present in the leaves of $T$. patula. It was extracted from leaves by solvent extraction and also by tissue culture. The results were analysed by Spectrophotometer, Fourier Transform Infrared Spectroscopy and larvicidal action.
\end{abstract}

Keywords: Thiophene; Leaves; Tissue culture

\section{Introduction}

Plant derived products are gaining importance in the field of biotechnology [1]. Apart from various advantages compared to synthetic products they provide low cost drugs and vaccines. But commercializing of these products is minimal due to lack of good manufacturing practices to field grown plants.

In the past years the plant kingdom has been of great interest as a source of potential of insecticidal products. In addition natural insecticides can provide core structures from which new insecticidal agents can be synthesized. Although the natural products are very effective against many insects, their synthetic preparation is not that efficacious. Plant insecticides still represent only a small fraction of the insecticidal material used very year. However as a consequence of stricter environmental legislation, increased resistance of pests to synthetic pesticides, growing residue awareness among the consumers, mounting industrial research and the development cost of chemical insecticides, there has been shift towards the interest for the use of natural insecticides. Thiophene is a photosensitive natural insecticide which is really effective and has many applications both in industrial and in pharmaceutical products.

The leaf tissue of $T$. patula was used to initiate the callus growth and the medium used was the Murashige and Skoog's with 2-4 dichlorophenoxyacetic acid and kinetin [2]. Maximum thiophene content and maximum biomass accumulation was recorded.

\section{Materials Required}

Marigold stem and leaf branches, Distilled water, Methanol, Hexane, 20.20 blade, solvent extractor, Bavistin, $0.1 \% \mathrm{HgCl}_{2}$, Hitastin, Glass Jar (250 ml), Soxhlet apparatus, MS medium.

\section{Procedure}

\section{Media preparation}

MS Medium (Stock): Medium prepared in varying concentration of hormones. Murashige and Skoog's medium was prepared using Macronutrients Stock 1 (Table 1), Macronutrients Stock 2 (Table 2), Macronutrients Stock 3 (Table 3), Micronutrients Stock 4 (Table 4) and Vitamins (Table 5). The medium for tissue culture contained macronutrients, micronutrients and vitamins. The components of MS medium (Stock 1) are ammonium nitrate, potassium nitrate, potassium dihydrogen phosphate and magnesium sulphate. Specific amounts of each were measured and the solution was made upto $1 \mathrm{~L}$ using distilled water. Stock 2 contained calcium chloride. Stock 3 contained disodium salt of EDTA and ferrous sulphate hydrate. Stock 4 contained
Magnesium sulphate tetrahydrate, zinc sulphate, boric acid, Potassium iodide, disodium molybdate, cuprous sulphate pentahydrate and cobalt chloride. Stock 5 contained glycine vitamins nicotinic acid, pyridoxine HCL and thiamine.

Media preparation: Stock solution from 1-5 were mixed in specific amounts. $20 \mathrm{ml}$ of stock I, $20 \mathrm{ml}$ of stock II, $10 \mathrm{ml}$ of stock III, $10 \mathrm{ml}$

\begin{tabular}{|l|c|}
\hline Components & Weight $\mathbf{( g / l )}$ \\
\hline Ammonium nitrate & 82.5 \\
\hline Potassium nitrate & 95 \\
\hline Potassium dihydrogen phosphate & 8.5 \\
\hline Magnesium sulphate & 18.5 \\
\hline
\end{tabular}

Murashige and Skoog's MS medium, Composition (ml/l).

Table 1: Macronutrients (Stock : I).

\begin{tabular}{|l|c|}
\hline Component & Weight $(\mathbf{g} / \mathbf{l})$ \\
\hline Calcium chloride & 22 \\
\hline
\end{tabular}

Table 2: Macronutrients (Stock: II).

\begin{tabular}{|l|c|}
\hline Components & Weight $\mathbf{( g / l )}$ \\
\hline Disodium salt of EDTA & 3.7 \\
\hline Ferrous sulphate hydrate & 2.8 \\
\hline
\end{tabular}

Table 3: Macronutrients (stock: III 20ml).

\begin{tabular}{|l|c|}
\hline Components & Weight $\mathbf{( g / l )}$ \\
\hline Magnesium sulphate tetra hydrate & 2.23 \\
\hline Zinc sulphate & 0.860 \\
\hline Boric acid & 0.620 \\
\hline Potassium iodide & 0.083 \\
\hline Disodium molybdate & 0.02 \\
\hline Cuprous sulphate penta hydrate & 0.002 \\
\hline Cobalt chloride & 0.002 \\
\hline
\end{tabular}

Table 4: Micronutrients (stock: IV 10ml).

${ }^{*}$ Corresponding author: Anisha Brigit Shajan, Department of Biotechnology, Sahrdaya College of Engineering and Technology, Kerala, India, E-mail: anishashajan@gmail.com

Received November 17, 2012; Accepted December 26, 2012; Published January 01,2013

Citation: Shajan AB, Anooja PA, Mitha VM, Paulson N, Sanooja K, et al. (2013) Production of Thiophene from Tagetus patula. J Plant Pathol Microb 4:155. doi:10.4172/2157-7471.1000155

Copyright: (c) 2013 Shajan AB, et al. This is an open-access article distributed under the terms of the Creative Commons Attribution License, which permits unrestricted use, distribution, and reproduction in any medium, provided the original author and source are credited. 


\begin{tabular}{|l|c|}
\hline Components & Weight $(\mathbf{m g} / \mathbf{l})$ \\
\hline Glycine & 200 \\
\hline Nicotinic acid & 50 \\
\hline Pyridoxine $\mathrm{HCl}$ & 50 \\
\hline Thymine $\mathrm{HCl}$ & 10 \\
\hline
\end{tabular}

Table 5: Vitamins (stock: V 10ml).

\begin{tabular}{|l|l|l|}
\hline & Kinetin & 2,4-D \\
\hline Media 1 & $0.1 \mathrm{mg}$ & $0.2 \mathrm{mg}$ \\
\hline Media 2 & $0.2 \mathrm{mg}$ & $0.4 \mathrm{mg}$ \\
\hline Media 3 & $0.3 \mathrm{mg}$ & $0.6 \mathrm{mg}$ \\
\hline Media 4 & $0.4 \mathrm{mg}$ & $0.075 \mathrm{mg}$ \\
\hline
\end{tabular}

Table 6: Concentration of hormones.

stock IV, $10 \mathrm{ml}$ of stock V Added 1\% myo- inositol, 3\% sucrose and different concentration of hormones: kinetin and 2-4 D (Table 6) were added with $\mathrm{pH}$ maintained at 5.8. Four medias of varying hormone concentration were prepared for callus culture.

\section{Tissue Culture}

\section{Sterilization}

The shoots of the Marigold plant were sterilized using disinfectant Bavistin. Shoots were cut at 2 internodes interval. Branches were placed in separate glass jars of $250 \mathrm{ml}$ capacity. Used autoclaved sterile water and kept swirling continuously to remove any remaining dirt. Then drain the water and fill the jar till half with mercuric chloride $(0.1 \%)$ and water and keep swirling for 5 minutes. Again drain out the liquid mixture and add sterile water and swirled for 5 minutes twice.

\section{Initiation}

Switch on the UV for 20 minutes before entering the lab. Surface sterilized the laminar hood (top and table) with ethanol. Sterilized all equipment to be used in the steripot (SHIMAS).The leaves were cut a bit away from the node [3] and put the leaf in various bottles containing full MS medium with same hormonal composition.

\section{Subculture}

The calluses obtained in different bottles were collected. Glass jars of $250 \mathrm{ml}$ capacity were filled with about $100 \mathrm{ml}$ of MS medium of varying hormonal concentration. The callus were then inserted a bit into different test media (1,2,3 and 4) with mouth facing the HEPA filter to avoid contamination. This procedure was repeated for two weeks [4] (Figure 1) shows the callus grown in medium, (Figures 2-4) show the callus growth observed on the fourth, eighth and twelfth day.

\section{Solvent extraction}

Fresh leaves of Marigold were taken and sterilized with distilled water. $500 \mathrm{ml}$ conical flask was filled with about $150 \mathrm{ml}$ of hexane. The soxhlet apparatus was set and water connection to top and bottom of the condenser was given. Temperature was set at about $65^{\circ} \mathrm{C}$. Extraction was continued for about 6 hours. Light pale yellow color extract was obtained in the conical flask (Figure 5). Stored the extract in dark bottles as thiophene is photoactive. After the initial extract was concentrated, it was again redissolved in hexane. The above procedure was repeated for callus of T. patula. Fourier Transform Infrared Analysis was done analysis for detection of thiophene.

\section{Results and Discussion}

The callus growth was observed in Media 1, 2, 3 and 4 (Figures
6-9). The figures show the size of the callus grown on four Medias. It was observed that the callus biomass was the highest in the media 4 containing $0.4 \mathrm{mg}$ kinetin and $0.075 \mathrm{mg} 2-4 \mathrm{D}$.

\section{Spectrophotometric analysis (Uv)}

Peak was observed in the range $200-250 \mathrm{~nm}$ for both extract of $T$. patula callus as well as T. patula leaves. The peak in the range of 200250 among other peaks was similar to the standard data for thiophene [5].

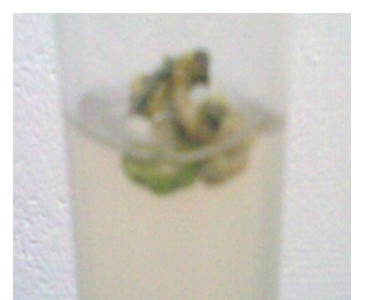

Figure 1: Test-tube containing callus.

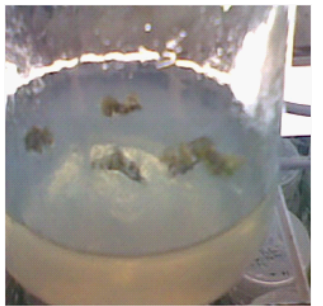

Figure 2: Callus observed on the fourth day.

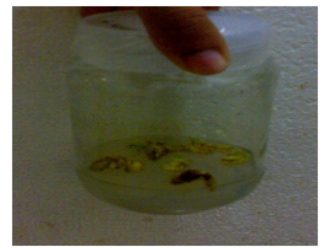

Figure 3: Callus observed on the eighth and twelfth day.

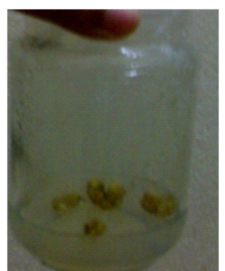

Figure 4: Callus observed on the eighth and twelfth day.

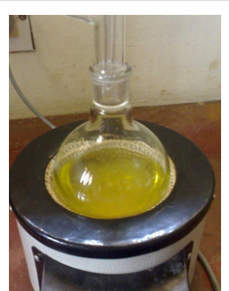

Figure 5: Marigold leaf extract with Hexane. 
Citation: Shajan AB, Anooja PA, Mitha VM, Paulson N, Sanooja K, et al. (2013) Production of Thiophene from Tagetus patula. J Plant Pathol Microb 4:155. doi:10.4172/2157-7471.1000155

Page 3 of 4

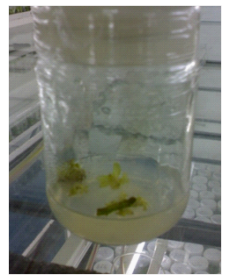

Figure 6: Media 1.

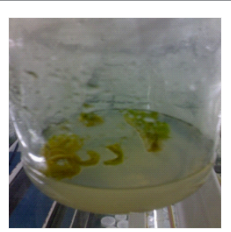

Figure 7: Media 2.

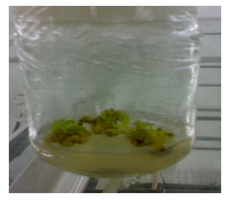

Figure 8: Media 3.

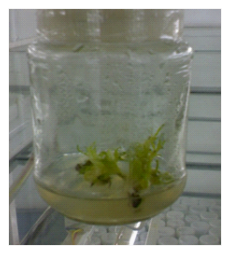

Figure 9: Media 4.

\section{Ft-Ir Spectrometric analysis}

The various derivatives of thiophene were observed at different wave numbers [6].

\section{Extract 1}

Callus culture of $T$. patula extracted with hexane as solvent was subjected to FT-IR spectroscopy. The result was as obtained in the table 7. The derivatives of hexane were observed at wave numbers in the range of $2969-2965 / \mathrm{cm}, 2929-2912 / \mathrm{cm}, 2884-2883 / \mathrm{cm}, 2861-2849 / \mathrm{cm}$, the compound observed was n-alkalene. At $1466-1468 / \mathrm{cm}$ n-alkanes were observed.

Thiophene derivatives were present from $1375-688 / \mathrm{cm}$. At $1375-$ $1360 / \mathrm{cm}, 1172-1165 / \mathrm{cm}, 1145-1165 / \mathrm{cm}, 1070-1040 / \mathrm{cm}, 1040-990 / \mathrm{cm}$, $984.30 / \mathrm{cm}, 884.59 / \mathrm{cm}, 818 / \mathrm{cm}, 760-650 / \mathrm{cm}, 730-720 / \mathrm{cm}$ and $688 / \mathrm{cm}$, the derivatives of thiophene: aliphatics sulfonates, pyrazoles, benzene, thiophene, tetra hydropyran, tert-butyl group, primary chloroalkanes and tetra hydro thiophene were present respectively.

\section{Extract 2}

Leaves of T. patula extracted with hexane as solvent and subjected to FT-IR spectroscopy. The result was as obtained in the table 8 . The derivatives of hexane were observed at wave numbers in the range $2969-2965 / \mathrm{cm}, 2929-2912 / \mathrm{cm}, 2884-2883 / \mathrm{cm}, 2861-2849 / \mathrm{cm}$ the compound observed was n-alkalene. At 1466-1468/cm n-alkanes was observed.

Thiophene derivatives were present from $1375-688 / \mathrm{cm}$. At $1375-$ $1360 / \mathrm{cm}, 1282-1275 / \mathrm{cm}, 1280-1240 / \mathrm{cm}, 1145-1165 / \mathrm{cm}, 1070-1040 /$ $\mathrm{cm}, 1040-990 / \mathrm{cm}, 1010-990 / \mathrm{cm}, 984.30 / \mathrm{cm}, 951.65 / \mathrm{cm}, 884.59 /$ $\mathrm{cm}, 818 / \mathrm{cm}, 760-650 / \mathrm{cm}$ and $730-720 / \mathrm{cm}$ represent derivatives of thiophene: secondary nitro alkanes, alkyl nitrates, epoxy derivatives, dialkyl sulfones, aliphatic sulfoxides, pyrazoles, Mono meta and 1,3,5 substituted benzene, benzene, methyl sulphonate, thiophene, tetra hydropyran, tert-butyl group and primary chloroalkanes were present respectively.

\section{Larvicidal test}

The solvent extract of T. patula callus and the leaves were used for

\begin{tabular}{|l|l|l|}
\hline $\begin{array}{l}\text { WAVE NUMBER } \\
\text { (FREQUENCY,/Cm) }\end{array}$ & VIBRATION & COMPOUND \\
\hline $2969-2965$ & Anti symmetric & n-alkalene \\
\hline $2929-2912$ & Antisymmetric $\mathrm{CH}_{2}$ stretch & n-alkalene \\
\hline $2884-2883$ & Symmetric $\mathrm{CH}_{3}$ stretch & n-alkalene \\
\hline $2861-2849$ & Symmetric $\mathrm{CH}_{2}$ stretch & n-alkalene \\
\hline $1466-1468$ & $\mathrm{CH}_{3}$ deformation & n-alkanes \\
\hline $1375-1360$ & Symmetric $\mathrm{NO}_{2}$ stretch & Secondary nitro alkanes \\
\hline $1282-1275$ & Symmetric $\mathrm{NO}_{2}$ stretch & Alkyl nitrates \\
\hline $1280-1240$ & Ring stretch & Epoxy derivatives \\
\hline $1172-1165$ & Symmetric $\mathrm{SO}_{2}$ stretch & Alkyl sulfonates \\
\hline $1145-1125$ & Symmetric $\mathrm{SO}_{2}$ stretch & Dialkyl sulfones \\
\hline $1070-1040$ & $\mathrm{~S}=\mathrm{O}$ stretch(1 or 2 bands) & Aliphatic sulfoxides \\
\hline $1040-990$ & Ring vibrations & Pyrazoles \\
\hline 984.30 & Ring breathing & Benzene \\
\hline 951.65 & $\mathrm{~S}$ bond $\mathrm{CH}_{3}$ rocking vibration & \\
\hline 884.59 & Weak vibration & Thiophene \\
\hline 818 & Ring breathing & Tetra hydro pyran \\
\hline $760-650$ & Symmetrical skeletal stretching & Tert-butyl group \\
\hline $730-720$ & Ccl stretch $\mathrm{PC}_{\text {conformation }}$ & Primary chloroalkanes \\
\hline 688 & Ring breathing & Tetra hydro thiophene \\
\hline & & \\
\hline
\end{tabular}

Table 7: FT-IR analysis of $T$. patula leaf callus.

\begin{tabular}{|l|l|l|}
\hline $\begin{array}{l}\text { WAVE NUMBER } \\
\text { (FREQUENCY,/Cm) }\end{array}$ & VIBRATION & COMPOUND \\
\hline $2969-2965$ & Anti symmetric & n-alkalene \\
\hline $2929-2912$ & Antisymmetric $\mathrm{CH}_{2}$ stretch & n-alkalene \\
\hline $2884-2883$ & Symmetric $\mathrm{CH}_{3}$ stretch & n-alkalene \\
\hline $2861-2849$ & Symmetric $\mathrm{CH}_{2}$ stretch & n-alkalene \\
\hline $1466-1468$ & $\mathrm{CH}_{3}$ deformation & n-alkanes \\
\hline $1375-1360$ & Symmetric $\mathrm{NO}_{2}$ stretch & Secondary nitro alkanes \\
\hline $1282-1275$ & Symmetric $\mathrm{NO}_{2}$ stretch & Alkyl nitrates \\
\hline $1280-1240$ & Ring stretch & Epoxy derivatives \\
\hline $1145-1125$ & Symmetric $\mathrm{SO}_{2}$ strectch & Dialkyl sulfones \\
\hline $1070-1040$ & S=O stretch(1 or 2 bands) & Aliphatic sulfoxides \\
\hline $1040-990$ & Ring vibrations & Pyrazoles \\
\hline $1010-990$ & Triagonal ring breathing & $\begin{array}{l}\text { Mono meta and 1,3,5 } \\
\text { substituted benzene }\end{array}$ \\
\hline 984.30 & Ring breathing & Benzene \\
\hline 951.65 & S bond $\mathrm{CH}_{3}$ rocking vibration & Methyl Sulphonate \\
\hline 884.59 & Weak vibration & Thiophene \\
\hline 818 & Ring breathing & Tetra hydro pyran \\
\hline $760-650$ & Symmetrical skeletal stretching & Tert-butyl group \\
\hline $730-720$ & CCl stretch $\mathrm{PC}$ conformation & Primary chloroalkanes \\
\hline
\end{tabular}

Table 8: FT-IR analysis of $T$. patula leaves. 
the larvicidal test. The mortality rate of mosquito larvae was observed to be $80 \%$ for callus and $60 \%$ for $T$. patula leaves.

\section{Conclusion}

From the above results we came to the conclusion that media 4 containing higher amounts of kinetin and lower amounts of 2-4 D produced callus of large biomass as compared to media 1,2 and 3.The amount of thiophene present in the callus is directly proportional to the biomass. Hence maximum thiophene content was present in the Media 4 calluses observed on the $12^{\text {th }}$ day.

The UV spectrophometric analysis showed the present of thiophene and its derivatives from 200-250 $\mathrm{nm}$ in both hexane extract of callus and leaves as compared to standard data.

The results of FT-IR analysis showed that thiophene and their derivative were present in both the leaf calluses of T. patula and in the leaves of T. patula. From the FT-IR analysis showed the presence of thiophene at $884.59 / \mathrm{cm}$ in both the callus and leaves extract.

Higher percentage of larvicidal action was observed in callus compared to that of leaves. The results of FT-IR analysis showed that thiophene and their derivatives were present in both the leaf callus of $T$. patula and in the leaves of T. patula. Thiophene acts specifically on superoxide dismutase enzyme present in the gut of mosquito and thereby leading to its death. The larvicidal action was observed to be $80 \%$ for leaf calluses and $60 \%$ for leaves of $T$. patula. The prominence of thiophene in callus than in the leaves was observed. The larvicidal action would help in repressing diseases such as malaria, dengue, chikungunya caused by mosquito as vector.

Hence thiophene presence was confirmed in callus and leaves by UV spectrophotometer analysis, FT-IR analysis and Larvicidal test.

\section{Acknowledgement}

We are extremely thankful to Hafi Biotech for the help and guidance. Also our sincere thanks to the HOD of Biotechnology Department Dr. Sasi Kumar and to our guide Professor Praveena. P for valuable support and encouragement.

\section{References}

1. Brodelius P, Deus B, Mosbach K, Zenk MH (1979) Immobilized plant cells for the production and transformation of natural products. FEBS Lett 103: 93-97.

2. Abe T, Futsuhara Y (1985) Efficient Plant Regeneration by Somatic Embryogenesis from Root Callus Tissues of Rice (Oryza sativa L.). J Plant Physiol 121: 111-118.

3. Chen TH, Lam L, Chen SC (1985) Somatic embryogenesis and plant regeneration from cultured young inflorescences of Oryza sativa L. (rice). Plant Cell Tissue Organ Cult 4: 51-54.

4. Furuya T, Orihara Y, Koge, K (1990) Long term culture and caffeine production of immobilized coffee (Coffea arabica) L. cells in polyurethane foam. Plant Cell Rep 9: 125-128.

5. Bongini A, Barbarella G, Zambianchi M, Arbizzania C, Mastragostino M (2000) Thiophene S-oxides: orbital energies and electrochemical properties. Chem commun 439-440.

6. Bessada C, Fuchs AH, Gallier J, Rousseau B (1989) Dynamic disorder in stable and metastable thiophene. - II. Non Lorentzian nuclear relaxation and glass transition. J Phys France 50: 855-859. 